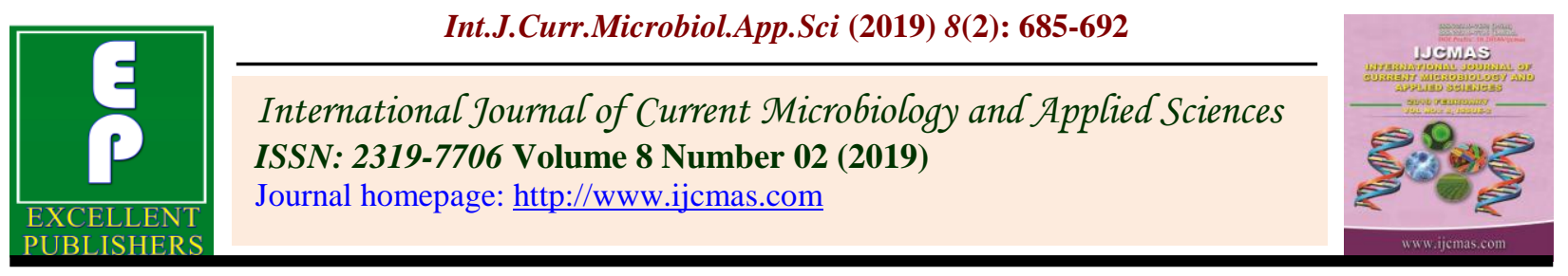

\title{
Impact of Date of Sowing and Nutrient Management on Yield and Nutrient Uptake of Bread Wheat (Triticum aestivum L.) Genotypes under Late Sown Irrigated Condition
}

\author{
Kiran Gurujal* and S.C. Alagundagi \\ Department of Agronomy, College of Agriculture, Vijayapura \\ University of Agricultural Sciences, Dharwad - 580 005, Karnataka, India \\ *Corresponding author
}

\section{Keywords}

Bread wheat, sowing date, fertilizer level, Nutrient uptake

Article Info

Accepted:

07 January 2019

Available Online:

10 February 2019

\section{A B S T R A C T}

Field experiment was conducted at Agricultural Research Station, Almel to study the Impact of date of sowing and nutrient management on yield and nutrient uptake of bread wheat (Triticum aestivum L.) genotypes under late sown irrigated condition during rabi 2014-15. The experiment was laid out in split-split plot design with three replications. There were three genotypes (HD-3090, NIAW-34 and DWR-195) in main plot treatments, two sowing date (December 15th and December 30th) in sub plot treatment and two fertilizer levels (100:75:50 and 125:93.75:62.5 kg N, $\mathrm{P}_{2} \mathrm{O}_{5}$ and $\mathrm{K}_{2} \mathrm{O}$ ha ${ }^{-1}$ ) in sub-sub plot treatments. The wheat genotype HD-3090 produced significantly higher grain yield (3628 $\left.\mathrm{kg} \mathrm{ha}^{-1}\right)$, straw yield $\left(5152 \mathrm{~kg} \mathrm{ha}^{-1}\right)$ and harvest index (40.88\%) compared to the genotype NIAW-34 (2710, $4142 \mathrm{~kg} \mathrm{ha}^{-1}$ and $39.53 \%$, respectively). Significantly higher yield was attributed to significantly higher nitrogen, phosphorus and potassium uptake at harvest (77.9, 17.4 and $91.9 \mathrm{~kg} \mathrm{ha}^{-1}$, respectively). The crop sown on December $15^{\text {th }}$ recorded significantly higher grain yield $\left(3260 \mathrm{~kg} \mathrm{ha}^{-1}\right)$, straw yield $\left(4810 \mathrm{~kg} \mathrm{ha}^{-1}\right)$ and nitrogen, phosphorus and potassium uptake at harvest $\left(72.9,15.7\right.$ and $85.5 \mathrm{~kg} \mathrm{ha}^{-1}$, respectively) compared to December $30^{\text {th }}$ sowing. Fertilizer level of 125:93.75:62.5 kg N, $\mathrm{P}_{2} \mathrm{O}_{5}$ and $\mathrm{K}_{2} \mathrm{O}$ $\mathrm{ha}^{-1}$ recorded significantly higher grain yield $\left(3111 \mathrm{~kg} \mathrm{ha}^{-1}\right)$, straw yield $\left(4713 \mathrm{~kg} \mathrm{~h}^{-1}\right)$ and nitrogen, phosphorus and potassium uptake at harvest $\left(74.7,15.9\right.$ and $86.5 \mathrm{~kg} \mathrm{ha}^{-1}$, respectively) compared to 125:93.75:62.5 $\mathrm{kg} \mathrm{N}, \mathrm{P}_{2} \mathrm{O}_{5}$ and $\mathrm{K}_{2} \mathrm{O}$ ha ${ }^{-1}$. Higher interaction effect of wheat genotype HD 3090 sown on December $15^{\text {th }}$ at fertilizer level of 125:93.75:62.5 kg N, $\mathrm{P}_{2} \mathrm{O}_{5}$ and $\mathrm{K}_{2} \mathrm{O}^{-1}{ }^{-1}$ recorded significantly higher grain yield (3983 kg $\left.\mathrm{ha}^{-1}\right)$, straw yield $\left(5519 \mathrm{~kg} \mathrm{ha}^{-1}\right)$ and harvest index (41.84\%) with higher nutrient uptake.

\section{Introduction}

Wheat (Triticum aestivum L.), India occupies first place with regard to area and second in production in the world. Importance of wheat in Indian agriculture is second only to rice. It is grown over an area of $29.8 \mathrm{~m}$ ha with total annual production of $95 \mathrm{~m} \mathrm{t}$ and productivity of $3.2 \mathrm{t} \mathrm{ha}^{-1}$ (Anon., 2014). In the Indian sub continent, is an important food grain providing nourishment nearly to 35 per cent people of the world. Wheat belongs to family 
Poaceae and is one of the leading cereals of many countries of the world. The states of Uttar Pradesh, Punjab and Haryana are the major wheat producers accounting for nearly 70 per cent of the total wheat produced in the country. Uttar Pradesh is the leading producer (25.03 $\mathrm{m} \mathrm{t}$ ) followed by Punjab and Haryana, while Punjab ranks first in productivity with $4207 \mathrm{~kg} \mathrm{ha}^{-1}$ (Anon., 2014). In Karnataka area under wheat is $0.26 \mathrm{~m}$ ha with production of $0.28 \mathrm{mt}$ and productivity of $1094 \mathrm{~kg} \mathrm{ha}^{-1}$ (www.ksda.nic.in, 2013-14). Karnataka is unique in cultivation of three species, namely, Triticum aestivum (bread wheat), Triticum durum (durum, macaroni or soji wheat) and Triticum dicoccum (dicoccum or emmer wheat). Major wheat growing area is under rainfed condition. Productivity is very low compared to national average, mainly because of non availability of longer cool growing period due to delayed commencement of lower air temperature during early stages and early commencement of higher temperature during its reproductive growth stages. As environmental condition in the vegetative phase determines the plant morphology and time of earing, dates of sowing of wheat crop become important for the final yield. Wheat is also highly responsive to nitrogen levels in the soil and therefore applying adequate doses through fertilizers and organic manure is vital for realizing optimum yield.

The combined application of $\mathrm{N}, \mathrm{P}_{2} \mathrm{O}_{5}$ and $\mathrm{K}_{2} \mathrm{O}$ fertilizers exhibited highest yield of wheat $\left(30.97 \mathrm{q} \mathrm{ha}^{-1}\right)$ with the highest uptake of $\mathrm{N}\left(64.4 \mathrm{~kg} \mathrm{ha}^{-1}\right), \mathrm{P}_{2} \mathrm{O}_{5}\left(9.69 \mathrm{~kg} \mathrm{ha}^{-1}\right)$ and $\mathrm{K}_{2} \mathrm{O}\left(248.30 \mathrm{~kg} \mathrm{ha}^{-1}\right)$, which was closely followed by the treatment where in $\mathrm{N}, \mathrm{K}$ and $\mathrm{Zn}$ were applied together. However, the results further indicated that the application of FYM exhibited a higher grain yield of wheat $(48.60 \%)$ over control suggesting a greater role of organic manures especially FYM towards increasing the yield of wheat (Maiti and Sarkar, 2003).
It is also the predominant rabi season crop in Northern Dry Zone of Karnataka under irrigated conditions. Being a thermosensitive crop, sowing time plays a vital role in the growth, yield and nutrient uptake of wheat and therefore must be considered as a nonmonetary input. Wheat being a heavy feeder of nutrients, heavy dose of fertilizers is a prerequisite for higher yield. Not much work has been done on the date of sowing and nutrient management on yield and nutrient uptake of bread wheat in the Zone 3 of Karnataka. Hence to study the individual as well as interaction effects of these two factors the experiment was planned.

\section{Materials and Methods}

A field experiment on "Impact of date of sowing and nutrient management on yield and nutrient uptake of bread wheat (Triticum aestivum L.) genotypes under late sown irrigated condition" was conducted during rabi 2014-15 at Agricultural Research Station, Almel which is situated in Northern dry zone (Zone 3$)$ of Karnataka state at $\left(16^{0}\right.$ 49' North latitude and $75^{\circ} 43^{\prime}$ and East longitude at an altitude of $593.8 \mathrm{~m}$ above the mean sea level), University of Agricultural Sciences, Dharwad (Karnataka). The experiment was laid out in split-split plot design with three replications. There were three genotypes (HD-3090, NIAW-34 and DWR-195) in main plot treatments, two sowing date (December 15th and December 30th) in sub plot treatment and two fertilizer levels (100:75:50 and 125:93.75:62.5 kg N, $\mathrm{P}_{2} \mathrm{O}_{5}$ and $\mathrm{K} 2 \mathrm{O} \mathrm{ha}^{-1}$ ) in sub-sub plot treatments. The soil of the experimental site was Vertisol (medium deep black soil). At the time of sowing half dose of nitrogen and full dose of phosphorus and potassium were applied as basal dose. Basal application was done in lines $5.0 \mathrm{~cm}$ by the side of the seed rows. The remaining 50 per cent nitrogen was top dressed at 30 days after sowing. The seeds 
were sown @ $150 \mathrm{~kg} \mathrm{ha}^{-1}$ at $23 \mathrm{~cm}$ row spacing by opening furrows with the help of marker. The seeds were treated with Azospirillum @2.0 kg per ha seed rate before sowing. Later the seeds were covered manually.

The crop was sown as per date of sowing i.e., on $15^{\text {th }}$ and $30^{\text {th }}$ December, 2014. All the cultural methods were adopted as per the state recommended package of practices. Irrigations were given as per the crop requirement.

The crop was harvested as and when the three genotypes matured at different time. Earliest matured variety was HD 3090, followed by DWR 195 and lastly, the variety NIWA genotypes matured during the month of April 2015. Five random plants were selected from each plot, excluding the border row, for taking growth observations.

The representative dry samples of Stover and grains were analysed for ascertaining the nutrient ( $\mathrm{N}, \mathrm{P}$ and $\mathrm{K}$ ) content. The $\mathrm{N}$ content was analysed by Micro Kjeldahl method expressed in percentage (Jackson, 1967), P content was analyzed by Vanadomolybdo phosphoric acid yellow-colour methods (Jackson, 1967) and K content was estimated by using flame photometer as described by Jackson (1967) respectively.

The data pertaining to each of the characters of the experimental crop were tabulated and finally analysed statistically by applying the standard technique to draw a valid conclusion. The experimental data were statistically analyzed using MSTAT-C programme. The level of significance used in $F$ test was $\mathrm{P}=0.05$. The mean values of interaction treatment were subjected to Duncan's Multiple Range Test (DMRT) using the corresponding error mean sum of squares and degrees of freedom values.

\section{Results and Discussion}

Response of bread wheat genotypes, date of sowing, fertilizer levels and their interaction on grain yield, straw yield and harvest index

The bread wheat genotype HD 3090 recorded significantly higher grain and straw yield (3628 and $5152 \mathrm{~kg}$ ha-1, respectively) compared to other genotypes. The yield increase was 25.27 and 19.60 per cent, respectively compared to NIAW 34 and DWR 195, respectively. And also HD 3090 genotype recorded significantly higher harvest index (40.88\%). Significantly higher yield of genotype HD 3090 could be attributed to its thermo-tolerant nature and significantly higher performance of yield. Similar findings of higher yield in wheat genotype were reported by Patil (1996), Wang et al., (1998) and Patel (1999). The significantly least grain and straw yield recorded with genotype NIAW-34 (2710 and $4142 \mathrm{~kg} \mathrm{ha}^{-1}$, respectively).

The crop sown on December $15^{\text {th }}$ recorded significantly higher grain and straw yield (3260 and $4810 \mathrm{~kg} \mathrm{ha}{ }^{-1}$, respectively) compared to December $30^{\text {th }}$ sowing. The yield increase with early sowing was 13.68 and 9.45 per cent, respectively over December $30^{\text {th }}$ sowing. And also crop sown on December $15^{\text {th }}$ recorded significantly higher harvest index (40\%) compared to December $30^{\text {th }}$ sowing. This was due to significantly higher yield.

The significantly least grain and straw yield recorded with crop sown on December $30^{\text {th }}$ (2814 and $4355 \mathrm{~kg} \mathrm{ha}^{-1}$, respectively) and also harvest index recorded significantly lower (39.17\%) was due to significantly lower yield. Similar results were reported by Ansary et al., (1989), Sial et al., (2005). 
Fertilizer level of 125:93.75:62.50 kg N, $\mathrm{P}_{2} \mathrm{O}_{5}$ and $\mathrm{K}_{2} \mathrm{O}$ ha $^{-1}$ recorded significantly higher grain and straw yield (3111and $4713 \mathrm{~kg} \mathrm{ha}^{-1}$, respectively) compared to RDF. The yield increase was 4.75 and 5.53 per cent, respectively compared to RDF.

Fertilizer levels did not influence significantly the harvest index. This was due to significantly higher yield. These findings are in agreement with Gami et al., (1986) and Yadav et al., (2014). The significantly least grain and straw yield recorded with fertilizer level of 100:75:50 kg N, $\mathrm{P}_{2} \mathrm{O}_{5}$ and $\mathrm{K}_{2} \mathrm{O}$ ha $^{-1}$ $\left(\mathrm{F}_{1}, 2963\right.$ and $4452 \mathrm{~kg} \mathrm{ha}^{-1}$, respectively) was due to significantly lower yield.

The interaction of genotype HD 3090 sown on December $15^{\text {th }}$ at fertilizer level of 125:93.75:62.5 kg N, $\mathrm{P}_{2} \mathrm{O}_{5}$ and $\mathrm{K}_{2} \mathrm{O}$ ha $^{-1}$ recorded significantly higher grain yield $\left(3983 \mathrm{~kg} \mathrm{ha}^{-1}\right)$, straw yield $\left(5519 \mathrm{~kg} \mathrm{ha}^{-1}\right)$ and harvest index (41.84\%). The grain and straw yield increase was 38.08 and 34.57 per cent, respectively compared to $100: 75: 50 \mathrm{~kg} \mathrm{~N}$, $\mathrm{P}_{2} \mathrm{O}_{5}$ and $\mathrm{K}_{2} \mathrm{O}$ ha ${ }^{-1}$. This was mainly due to significantly higher yield. These results are in agreement with Bharti et al., (1987).

The next best significantly higher interaction for grain yield (3851 kg ha-1), straw yield $\left(5187 \mathrm{~kg} \mathrm{ha}^{-1}\right)$ and harvest index $(41.11 \%)$ was recorded with genotype HD 3090 sown on December $15^{\text {th }}$ at fertilizer level of 100:75:50 kg N, $\mathrm{P}_{2} \mathrm{O}_{5}$ and $\mathrm{K}_{2} \mathrm{O}$ ha ${ }^{-1}$. This was mainly due to significantly higher performance of yield.

The interaction genotype NIAW 34 sown on December $30^{\text {th }}$ at fertilizer level of 100:75:50 $\mathrm{N}, \quad \mathrm{P}_{2} \mathrm{O}_{5}$ and $\mathrm{K}_{2} \mathrm{O} \quad \mathrm{kg}^{\mathrm{ha}} \mathrm{ha}^{-1}$ recorded significantly lower grain yield $\left(2466 \mathrm{~kg} \mathrm{ha}^{-1}\right)$ and straw yield $\left(3611 \mathrm{~kg} \mathrm{ha}^{-1}\right)$. This was due to significantly lower yield with this interaction and the significantly least individual effect of genotype, date of sowing and fertilizer level. Similar results were also reported by Shah et al., (2006) and Tahir et al., (2009).

Response of bread wheat genotypes, date of sowing, fertilizer levels and their interaction on nutrient uptake (N, P and $\mathrm{K}$ )

Increased availability of nutrients due to build up of soil microflora which consequently increases the nutrient release from soil and enzymatic activity helps in increased uptake of nutrients (Boomathi et al., 2005). Higher grain yield was attributed to the higher uptake of applied nutrients by the crop.

Among the genotypes, HD 3090 recorded significantly higher uptake of nitrogen, phosphorus and potassium at 60 DAS (61.5, 10.3 and $74.4 \mathrm{~kg} \mathrm{~N}, \mathrm{P}_{2} \mathrm{O}_{5}$ and $\mathrm{K}_{2} \mathrm{O} \mathrm{ha}^{-1}$, respectively) and at $(77.9,17.4$ and $91.9 \mathrm{~kg} \mathrm{~N}$, $\mathrm{P}_{2} \mathrm{O}_{5}$ and $\mathrm{K}_{2} \mathrm{O}^{-1}{ }^{-1}$, respectively) compared to DWR-195. This was due to significantly higher performance of nutrient uptake.

Nutrient uptake at 60 DAS was significantly higher with crop sown on December $15^{\text {th }}$ (57.8, 8.7 and $69.6 \mathrm{~kg} \mathrm{~N}, \mathrm{P}_{2} \mathrm{O}_{5}$ and $\mathrm{K}_{2} \mathrm{O} \mathrm{ha}^{-1}$, respectively) compared to December $30^{\text {th }}$ sowing. This was due to prolonged winter period available to early sown crop with better growth and yield. At harvest, plant nutrient uptake did not differ significantly.

The fertilizer level of 125:93.75:62.5 kg N, $\mathrm{P}_{2} \mathrm{O}_{5}$ and $\mathrm{K}_{2} \mathrm{O}^{-1}{ }^{-1}$, respectively (125\% RDF) recorded significantly higher nutrient uptake at 60 DAS $\left(\mathrm{F}_{2}, 57.6,8.7\right.$ and $69.3, \mathrm{~kg} \mathrm{~N}, \mathrm{P}_{2} \mathrm{O}_{5}$ and $\mathrm{K}_{2} \mathrm{O}$ ha ${ }^{-1}$, respectively) and at harvest $\left(\mathrm{F}_{2}\right.$, 74.7, 15.9 and 86.5, $\mathrm{kg} \mathrm{N}, \mathrm{P}_{2} \mathrm{O}_{5}$ and $\mathrm{K}_{2} \mathrm{O} \mathrm{ha}^{-1}$, respectively) compared to lower fertilizer level $(100 \% \mathrm{RDF})$. This was due to higher response of the crop to higher nutrition leading to higher yield. These results are in conformity with the finding of Pradhan et al., (1990) and Bhogal et al., (1996) (Table 1). 
Table.1 Impact of date of sowing and nutrient management on grain yield, straw yield, harvest index and nutrient uptake of bread wheat genotypes under late sown irrigated condition

\begin{tabular}{|c|c|c|c|c|c|c|c|c|c|c|c|c|}
\hline \multirow[t]{2}{*}{ Treatment } & \multicolumn{3}{|c|}{$\begin{array}{l}\text { Available nutrient status in soil } \\
\text { after harvest }\left(\mathrm{kg} \mathrm{ha}^{-1}\right)\end{array}$} & \multicolumn{3}{|c|}{$\begin{array}{l}\text { Total nutrient uptake at } \\
60 \text { DAS }\left(\mathrm{kg} \mathrm{ha}^{-1}\right)\end{array}$} & \multicolumn{3}{|c|}{$\begin{array}{l}\text { Total nutrient uptake at } \\
\text { harvest }\left(\mathrm{kg} \mathrm{ha}^{-1}\right)\end{array}$} & \multirow{2}{*}{$\begin{array}{c}\text { Grain } \\
\text { yield } \\
\left(\mathrm{kg} \mathrm{ha}^{-1}\right)\end{array}$} & \multirow{2}{*}{$\begin{array}{c}\text { Straw } \\
\text { yield } \\
\left(\mathrm{kg} \mathrm{ha}^{-1}\right)\end{array}$} & \multirow[t]{2}{*}{$\begin{array}{l}\text { Harvest } \\
\text { index }(\%)\end{array}$} \\
\hline & $\mathbf{N}$ & $\mathrm{P}_{2} \mathrm{O}_{5}$ & $\mathbf{K}_{2} \mathbf{O}$ & $\mathbf{N}$ & $\mathbf{P}_{2} \mathrm{O}_{5}$ & $\mathrm{~K}_{2} \mathrm{O}$ & $\mathbf{N}$ & $\mathbf{P}_{2} \mathrm{O}_{5}$ & $\mathrm{~K}_{2} \mathrm{O}$ & & & \\
\hline \multicolumn{13}{|c|}{ Genotypes (G) } \\
\hline $\mathbf{G}_{1}$ & $248.3^{c}$ & $26.1^{c}$ & $353.7^{b}$ & $61.5^{\mathrm{a}}$ & $10.3^{\mathrm{a}}$ & $74.4^{\mathrm{a}}$ & $77.9^{\mathrm{a}}$ & $17.4^{\mathrm{a}}$ & $91.9^{\mathrm{a}}$ & $3628^{a}$ & $5152^{a}$ & $40.88^{a}$ \\
\hline $\mathbf{G}_{2}$ & $262.2^{\mathrm{a}}$ & $28.5^{\mathrm{a}}$ & $366.9^{\mathrm{a}}$ & $53.2^{b}$ & $7.2^{b}$ & $62.7^{c}$ & $65.9^{c}$ & $13.3^{c}$ & $77.0^{c}$ & $2710^{b}$ & $4142^{c}$ & $39.53^{b}$ \\
\hline $\mathbf{G}_{3}$ & $253.4^{b}$ & $27.2^{b}$ & $357.5^{a b}$ & $56.7^{\mathrm{ab}}$ & $7.8^{b}$ & $68.4^{b}$ & $72.9^{b}$ & $14.8^{b}$ & $83.7^{b}$ & $2772^{b}$ & $4454^{b}$ & $38.32^{b}$ \\
\hline S.Em \pm & 1.0 & 0.4 & 2.8 & 1.4 & 0.3 & 0.5 & 0.2 & 0.3 & 1.2 & 74 & 77 & 0.28 \\
\hline \multicolumn{13}{|c|}{ Date of sowing (D) } \\
\hline$D_{1}$ & $254.0^{\mathrm{a}}$ & $27.5^{\mathrm{a}}$ & $360.3^{\mathrm{a}}$ & $57.8^{\mathrm{a}}$ & $8.7^{\mathrm{a}}$ & $69.6^{\mathrm{a}}$ & $72.9^{\mathrm{a}}$ & $15.7^{\mathrm{a}}$ & $85.5^{\mathrm{a}}$ & $3260^{a}$ & $4810^{a}$ & $40.0^{\mathrm{a}}$ \\
\hline $\mathrm{D}_{2}$ & $255.2^{\mathrm{a}}$ & $27.0^{\mathrm{a}}$ & $358.4^{\mathrm{a}}$ & $56.6^{b}$ & $8.2^{b}$ & $67.4^{b}$ & $71.4^{\mathrm{a}}$ & $14.7^{\mathrm{a}}$ & $82.8^{b}$ & $2814^{b}$ & $4355^{b}$ & $39.17^{b}$ \\
\hline S.Em. \pm & 0.9 & 0.4 & 1.6 & 0.2 & 0.1 & 0.4 & 0.6 & 0.5 & 0.5 & 34 & 41 & 0.25 \\
\hline \multicolumn{13}{|c|}{ Fertilizer levels (F) } \\
\hline$F_{1}$ & $253.0^{b}$ & $26.4^{b}$ & $357.6^{b}$ & $56.6^{b}$ & $8.2^{b}$ & $67.7^{b}$ & $69.8^{b}$ & $14.5^{b}$ & $81.9^{b}$ & $2963^{b}$ & $4452^{b}$ & $39.6^{\mathrm{a}}$ \\
\hline $\mathbf{F}_{2}$ & $256.3^{a}$ & $28.2^{\mathrm{a}}$ & $361.1^{\mathrm{a}}$ & $57.6^{\mathrm{a}}$ & $8.7^{\mathrm{a}}$ & $69.3^{\mathrm{a}}$ & $74.7^{\mathrm{a}}$ & $15.9^{\mathrm{a}}$ & $86.5^{\mathrm{a}}$ & $3111^{\mathrm{a}}$ & $4713^{a}$ & $39.6^{\mathrm{a}}$ \\
\hline S.Em \pm & 0.9 & 0.3 & 0.8 & 0.2 & 0.1 & 0.3 & 0.5 & 0.1 & 0.7 & 37 & 16 & 0.22 \\
\hline \multicolumn{13}{|c|}{ Interaction (GxDxF) } \\
\hline $\mathbf{G}_{1} \mathbf{D}_{1} \mathbf{F}_{1}$ & $248.4^{\mathrm{cd}}$ & $25.5^{\mathrm{de}}$ & $352.2^{\mathrm{e}}$ & $61.0^{b}$ & $10.8^{b}$ & $74.7^{\mathrm{a}}$ & $75.6^{b}$ & $17.6^{b}$ & $91.4^{\mathrm{ab}}$ & $3851^{\mathrm{a}}$ & $5187^{b}$ & $41.11^{\mathrm{a}}$ \\
\hline$G_{1} D_{1} F_{2}$ & $251.7^{\mathrm{cd}}$ & $26.9^{b-d}$ & $355.9^{c-e}$ & $63.2^{\mathrm{a}}$ & $12.2^{\mathrm{a}}$ & $76.0^{a}$ & $82.0^{a}$ & $19.3^{a}$ & $96.6^{\mathrm{a}}$ & $3983^{a}$ & $5519^{a}$ & $41.84^{\mathrm{a}}$ \\
\hline$G_{1} D_{2} F_{1}$ & $244.7^{d}$ & $24.6^{\mathrm{e}}$ & $351.6^{\mathrm{e}}$ & $60.3^{b}$ & $8.7^{d}$ & $72.1^{b}$ & $75.0^{b}$ & $15.7^{c}$ & $87.5^{b c}$ & $3290^{\mathrm{cd}}$ & $4911^{c}$ & $40.10^{\mathrm{ab}}$ \\
\hline$G_{1} D_{2} F_{2}$ & $248.5^{\mathrm{cd}}$ & $27.3^{b-d}$ & $355.0^{\mathrm{c}-\mathrm{e}}$ & $61.5^{b}$ & $9.4^{\mathrm{c}}$ & $74.9^{a}$ & $78.8^{a b}$ & $17.3^{b}$ & $92.1^{\mathrm{ab}}$ & $3390^{b c}$ & $4991^{c}$ & $40.44^{\mathrm{ab}}$ \\
\hline$G_{2} D_{1} F_{1}$ & $260.1^{\mathrm{ab}}$ & $28.1^{\mathrm{a}-\mathrm{c}}$ & $366.5^{\mathrm{a}}$ & $54.1^{\mathrm{de}}$ & $7.5^{\text {ef }}$ & $63.3^{\text {ef }}$ & $65.1^{\mathrm{de}}$ & $12.9^{g h}$ & $75.7^{\mathrm{fg}}$ & $2793^{f}$ & $4337^{f}$ & $39.18^{b c}$ \\
\hline$G_{2} D_{1} F_{2}$ & $263.2^{\mathrm{a}}$ & $29.9^{a}$ & $369.6^{\mathrm{a}}$ & $54.3^{\mathrm{de}}$ & $7.7^{\text {ef }}$ & $63.9^{\text {ef }}$ & $69.2^{c}$ & $14.4^{\mathrm{d}-\mathrm{f}}$ & $80.2^{\mathrm{d}-\mathrm{f}}$ & $3079^{\text {de }}$ & $4592^{\mathrm{de}}$ & $40.17^{\mathrm{ab}}$ \\
\hline$G_{2} D_{2} F_{1}$ & $261.0^{\mathrm{ab}}$ & $26.9^{b-d}$ & $364.4^{\mathrm{ab}}$ & $51.3^{f}$ & $6.6^{g}$ & $60.7^{\mathrm{g}}$ & $62.2^{\mathrm{e}}$ & $12.3^{h}$ & $73.8^{g}$ & $2466^{g}$ & $3611^{\mathrm{h}}$ & $40.50^{\mathrm{ab}}$ \\
\hline $\mathbf{G}_{2} \mathbf{D}_{2} \mathbf{F}_{2}$ & $264.3^{a}$ & $28.9^{\mathrm{ab}}$ & $367.0^{\mathrm{a}}$ & $53.1^{\mathrm{e}}$ & $7.2^{\mathrm{fg}}$ & $62.9^{\mathrm{fg}}$ & $67.2^{\mathrm{cd}}$ & $13.7^{\mathrm{fg}}$ & $78.2^{\mathrm{e}-\mathrm{g}}$ & $2505^{g}$ & $4026^{g}$ & $38.28^{c}$ \\
\hline$G_{3} D_{1} F_{1}$ & $252.2^{c}$ & $27.0^{b-d}$ & $357.6^{c-e}$ & $57.7^{c}$ & $8.0^{\text {de }}$ & $69.6^{b c}$ & $70.7^{c}$ & $14.4^{\mathrm{d}-\mathrm{f}}$ & $82.4^{c-e}$ & $2888^{\text {ef }}$ & $4535^{\mathrm{e}}$ & $38.90^{b c}$ \\
\hline$G_{3} D_{1} F_{2}$ & $255.7^{b c}$ & $28.4^{\mathrm{ab}}$ & $360.1^{b c}$ & $58.3^{c}$ & $8.1^{\mathrm{de}}$ & $70.0^{b c}$ & $75.3^{b}$ & $15.4^{\mathrm{cd}}$ & $87.0^{b c}$ & $2965^{\text {ef }}$ & $4690^{d}$ & $38.73^{b c}$ \\
\hline$G_{3} D_{2} F_{1}$ & $251.4^{\mathrm{cd}}$ & $25.9^{\mathrm{c}-\mathrm{e}}$ & $353.1^{\text {de }}$ & $55.2^{d}$ & $7.5^{\mathrm{ef}}$ & $65.9^{\mathrm{de}}$ & $69.9^{c}$ & $14.1^{\text {ef }}$ & $80.4^{\mathrm{d}-\mathrm{f}}$ & $2489^{g}$ & $4129^{g}$ & $37.60^{c}$ \\
\hline$G_{3} D_{2} F_{2}$ & $254.3^{\mathrm{cd}}$ & $27.5^{b-d}$ & $359.2^{b-d}$ & $55.5^{d}$ & $7.6^{\text {ef }}$ & $68.0^{\mathrm{cd}}$ & $75.5^{b}$ & $15.2^{\mathrm{c}-\mathrm{e}}$ & $85.1^{\mathrm{cd}}$ & $2746^{f}$ & $4463^{e}$ & $38.07^{c}$ \\
\hline S.Em. \pm & 2.1 & 0.7 & 2.0 & 0.5 & 0.2 & 0.8 & 1.2 & 0.4 & 1.7 & 89 & 40 & 0.53 \\
\hline
\end{tabular}

Means followed by the same lower case letter(s) in a column do not differ significantly by DMRT $(\mathrm{P}=0.05)$.

$\mathrm{G}_{1}$ : H D-3090

$\mathrm{G}_{2}$ : NIAW-34

$\mathrm{D}_{1}: 15-12-2014 \quad: 100: 75: 50 \mathrm{~kg} \mathrm{ha}^{-1} \mathrm{~N}, \mathrm{P}_{2} \mathrm{O}_{5}$ and $\mathrm{K}_{2} \mathrm{O}(100 \% \mathrm{RDF})$

$\mathrm{G}_{3}$ : DWR-195

$\mathrm{D}_{2}: 30-12-2014$

: 125:93.75:62.5 kg ha ${ }^{-1} \mathrm{~N}, \mathrm{P}_{2} \mathrm{O}_{5}$ and $\mathrm{K}_{2} \mathrm{O}(125 \% \mathrm{RDF})$ 

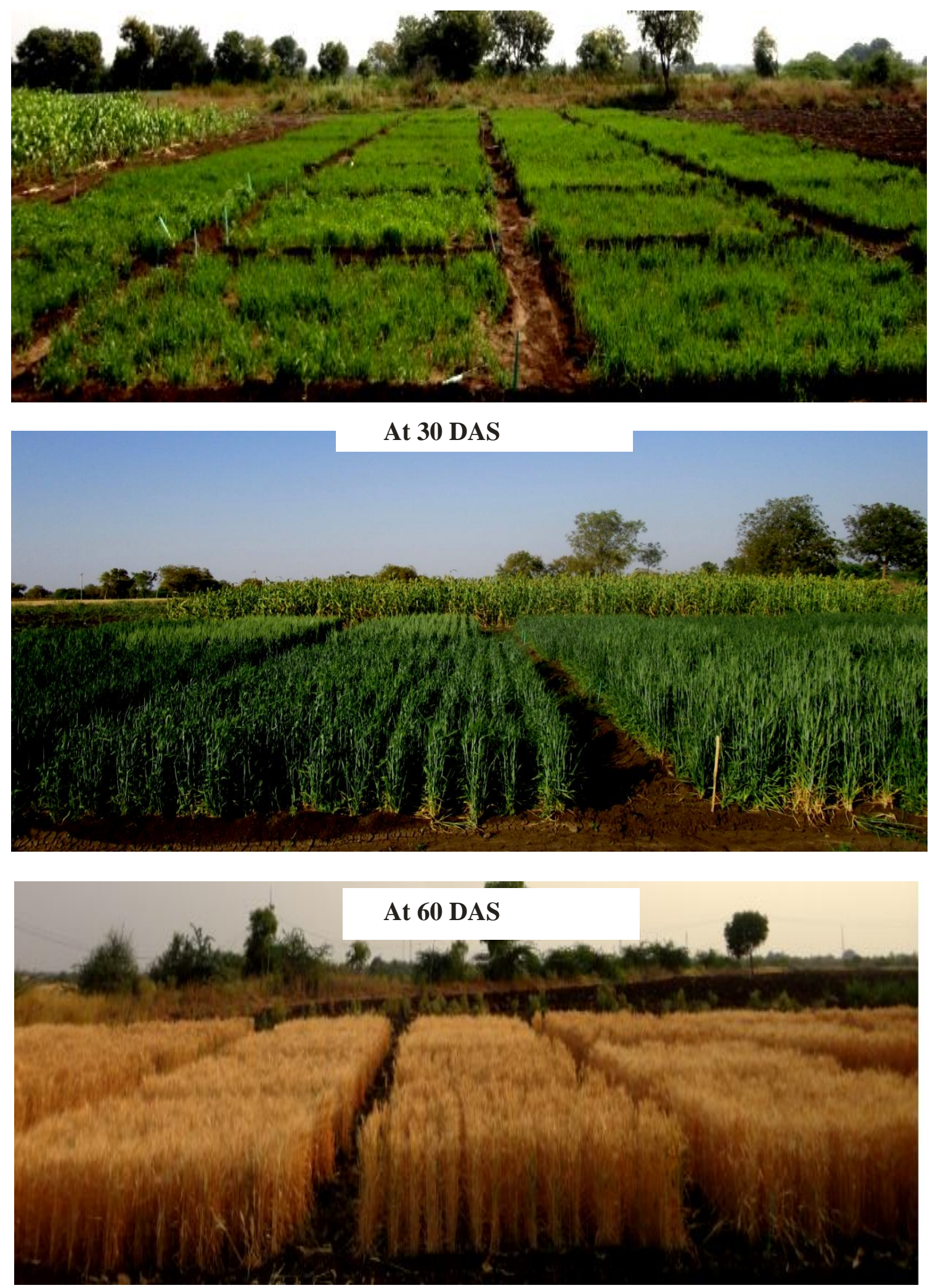

At harvest

General view of the experiment plot 
The interaction $\mathrm{G}_{1} \mathrm{D}_{1} \mathrm{~F}_{2}$ i.e. genotype $\mathrm{HD}$ 3090 sown on December $15^{\text {th }}$ at fertilizer level of 125:93.75:62.5 kg N, $\mathrm{P}_{2} \mathrm{O}_{5}$ and $\mathrm{K}_{2} \mathrm{O}$ ha ${ }^{-1}$ recorded significantly higher total nutrient uptake by the crop at 60 DAS $(63.2,12.2$ and $76.0 \mathrm{~kg} \mathrm{~N}, \mathrm{P}_{2} \mathrm{O}_{5}$ and $\mathrm{K}_{2} \mathrm{O} \mathrm{ha}^{-1}$, respectively) and at harvest $\left(82.0,19.3\right.$ and $96.6 \mathrm{~kg} \mathrm{~N}, \mathrm{P}_{2} \mathrm{O}_{5}$ and $\mathrm{K}_{2} \mathrm{O}$ ha $^{-1}$, respectively). This was due to significantly higher performance of nutrient uptake obtained with higher fertilizer level. Next best interaction was $\mathrm{G}_{1} \mathrm{D}_{1} \mathrm{~F}_{1}$ i.e. genotype HD 3090 sown on December $15^{\text {th }}$ at fertilizer level of 100:75:50 kg N, $\mathrm{P}_{2} \mathrm{O}_{5}$ and $\mathrm{K}_{2} \mathrm{O}$ ha $^{-1}$. Significantly least nutrient uptake was with interaction $\mathrm{G}_{2} \mathrm{D}_{2} \mathrm{~F}_{1}$ i.e genotype NIAW 34 sown on December $30^{\text {th }}$ at fertilizer level of 100:75:50 kg N, $\mathrm{P}_{2} \mathrm{O}_{5}$ and $\mathrm{K}_{2} \mathrm{O}$ ha $^{-1}$.

\section{Available nitrogen, phosphorus and potassium in soil after harvest}

Significantly higher available nutrient status in the soil after harvest was recorded with the genotypes, NIAW-34 (262.2, 28.5 and 366.9 $\mathrm{kg} \mathrm{N}, \mathrm{P}_{2} \mathrm{O}_{5}$ and $\mathrm{K}_{2} \mathrm{O} \mathrm{ha}^{-1}$, respectively) compared to genotype DWR-195 (253.4, 27.2 and $357.5 \mathrm{~kg} \mathrm{~N}, \mathrm{P}_{2} \mathrm{O}_{5}$ and $\mathrm{K}_{2} \mathrm{O} \mathrm{ha}^{-1}$, respectively). This was due to lower response of genotype NIAW-34 to applied nutrients. The results are in line with the findings of the Babhulkar et al., (2000). This was no significant effect on available soil nutrient status in the date of sowing. The fertilizer level of 125:93.75:62.5 kg N, $\mathrm{P}_{2} \mathrm{O}_{5}$ and $\mathrm{K}_{2} \mathrm{O}$ $\mathrm{ha}^{-1}$ recorded significantly higher available nitrogen, phosphorus and potassium in the soil after harvest of the crop $\left(\mathrm{F}_{2}, 256.3,28.2\right.$ and $361.1 \mathrm{~kg} \mathrm{~N}, \mathrm{P}_{2} \mathrm{O}_{5}$ and $\mathrm{K}_{2} \mathrm{O} \mathrm{ha}^{-1}$, respectively) compared to the 100: $75: 50 \mathrm{~kg}$ $\mathrm{N}, \mathrm{P}_{2} \mathrm{O}_{5}$ and $\mathrm{K}_{2} \mathrm{O}$ ha $^{-1}\left(\mathrm{~F}_{1}, 253,26.4\right.$ and 357.6 $\mathrm{kg} \mathrm{N}, \mathrm{P}_{2} \mathrm{O}_{5}$ and $\mathrm{K}_{2} \mathrm{O}$ ha ${ }^{-1}$, respectively). These finding are in agreement with Pradhan et al., (1990). The interaction $\mathrm{G}_{2} \mathrm{D}_{1} \mathrm{~F}_{2}$ i.e. genotype NIAW-34 sown on December $15^{\text {th }}$ at fertilizer level of 125:93.75:62.5 kg N, $\mathrm{P}_{2} \mathrm{O}_{5}$ and $\mathrm{K}_{2} \mathrm{O}$ $\mathrm{ha}^{-1}$ recorded significantly higher available nitrogen, phosphorus and potassium (263.2, 29.9 and $369.6 \mathrm{~kg} \mathrm{~N}, \mathrm{P}_{2} \mathrm{O}_{5}$ and $\mathrm{K}_{2} \mathrm{O} \mathrm{ha}{ }^{-1}$, respectively) in the soil. This was due to lower response of genotype NIAW-34 to applied nutrients. Significantly least available nitrogen, phosphorus and potassium in soil was recorded with interaction $\mathrm{G}_{1} \mathrm{D}_{2} \mathrm{~F}_{1}$ i.e. genotype HD-3090 sown on December $30^{\text {th }}$ at fertilizer level of 100:75:50 kg N, $\mathrm{P}_{2} \mathrm{O}_{5}$ and $\mathrm{K}_{2} \mathrm{O}$ ha $^{-1}\left(244.7,24.6\right.$ and $351.6 \mathrm{~kg} \mathrm{~N}, \mathrm{P}_{2} \mathrm{O}_{5}$ and $\mathrm{K}_{2} \mathrm{O} \mathrm{ha}^{-1}$, respectively). This might be due higher response of genotype HD-3090 to applied nutrients.

In conclusion, the wheat genotype HD 3090 sown on December $15^{\text {th }}$ at fertilizer level of 125:93.75:62.5 kg N, $\mathrm{P}_{2} \mathrm{O}_{5}$ and $\mathrm{K}_{2} \mathrm{O}$ ha $^{-1}$ recorded significantly higher grain yield $\left(3983 \mathrm{~kg} \mathrm{ha}^{-1}\right)$ with better nutrient uptake in Northern dry zone of Karnataka during late rabi irrigated situation.

\section{References}

Anonymous, 2014, Project Directors Report, Directorate of Wheat Research, ICAR, Karnal, Haryana.

Ansary, A. H., Khushak, A. M., Sethar, M. A., Ariam, N. A. and Emon, M. Y. M., 1989, Effect of sowing dates on growth and yield of wheat cultivars. Pakistan. J. Sci. Res., 32: 39-42.

Babhulkar, R.S., 2000, Residual effect of long term application of FYM and fertilizer on soil properties and yield of soybean. J. Ind. Soc. Soil Sci., 48: 89-92.

Bhogal, A., Young, S. D., Ralph, R., Sylvester, B. and Craigon, J., 1996, Modelling the residual effects of phosphate fertilizer in Repsley (UK). Fertilizer Res., 44: 27-36.

Bharti, A., Tejsingh, H. S. and Paroda, A. S., 1987, Response of late sown wheat varieties to nitrogen. Indian J. Agron., 32(3): 250-253.

Boomathi, N., Suganya Kanna, S. and 
Jeyaranni, S., 2005, Panchagavya - A gift from our mother's nature. Agrobios. Newlett. 4 (3): 20-21.

Jackson, M. L., 1967, Soil chemical analysis. Prentice Hall, India Pvt. Ltd., New Delhi, p 498.

Gami, J. K., Parmar, M. T., Patel, J. C. and Malavia, 1986, Effect of rates and method of nitrogen application on dwarf wheat. Indian J. Agron., 31(4): 401-402.

Maiti, D. and Sarkar, S. R., 2003, Integrated nutrient management for sustainable wheat production and $\mathrm{N}, \mathrm{P}, \mathrm{K}$ and $\mathrm{Zn}$ uptake by wheat in a haplaquept. Indian Agric., 47:125-130.

Patel, J. R., 1999, Effect of levels and methods of nitrogen application on wheat yield. J. Maharashtra Agric. Univ., 24: 108-109.

Patil, R. H., 1996, Response of dicoccum wheats to sowing dates and nitrogen level s under irrigated condition. $M$. Sc. (Agri.) Thesis, Univ. of Agric. Sci., Dharwad. India.

Pradhan, L., Rout, D., Barik, T. and Patro, G. K., 1990, Response of wheat to nitrogen, phosphorus, potash and zinc under irrigated conditions. Env. Ecol., 8:777-779.
Shah, W.A., Bakht, J., Ullah, T., Khan, A.W., Zubair, M. and Khakwani, A., 2006, Effect of sowing dates on yield and yield components of different wheat varieties. J. Agron., 5(1): 106-110.

Sial, M. A., Arain, A. M., Mazhar, H. S. K., Dahot, U. M. and Nizamani, N. A., 2005, Yield and quality parameters of wheat genotypes as affected by sowing dates and high temperature stress. Pakistan J. Bot., 37(3): 575-584.

Tahir, M., Ali, A., Nadeem, M, A., Hussain, A. and Khalid, F, 2009, Effect of different sowing dates on growth and yield of wheat (Triticum aestivum L.) varieties in district Jhang, Pakistan. Pakistan J. Life Soc. Sci., 7(1):66-69.

Yadav, M. K., Singh, R. K. and Yadav, S. K., 2014, Production potential and nutrient uptake of wheat (Triticum aestivum) as affected by organic sources of nutrients and micronutrients. Indian J. Agric. Sci., 84 (1): 121-124.

Wang, H. Y., Zhang, J. and Bao, G. G., 1998, Analysis of yield components of wheat and high cultivation methods in coastal areas. Jiangsu Agric. Sci., 6:5-7.

\section{How to cite this article:}

Kiran Gurujal and Alagundagi, S.C. 2019. Impact of Date of Sowing and Nutrient Management on Yield and Nutrient Uptake of Bread Wheat (Triticum aestivum L.) Genotypes under Late Sown Irrigated Condition. Int.J.Curr.Microbiol.App.Sci. 8(02): 685-692.

doi: https://doi.org/10.20546/ijcmas.2019.802.078 